\title{
LII. Sketch of the geology of Madeira. in a Letter addressed to G. B. Greenough, President of the Geological Society, and communicated by him to the Society
}

\author{
Hon. Henry Grey Bennett
}

To cite this article: Hon. Henry Grey Bennett (1811) LII. Sketch of the geology of Madeira. in a Letter addressed to G. B. Greenough, President of the Geological Society, and communicated by him to the Society, Philosophical Magazine Series 1, 38:162, 284-289, DOI: 10.1080/14786441108638648

To link to this article: http://dx.doi.org/10.1080/14786441108638648

$$
\text { 曲 Published online: } 27 \text { Jul } 2009 .
$$

Submit your article to this journal ए

\section{山ll Article views: 3}

Q View related articles ¿ك 
LII. Sketch of the Geology of Madeira. By the Hon. Henry Grey BennetT; in a Letter addressed to G. B. Grennovgh, President of the Geological Society, and communicated by him to the Society*.

$\mathrm{T}$

last summer in the island of Madeira. As there appears to be but little known of the structure, or of the phænomena which the strata in that island exhibit, the following observations may nat perhaps be wholly unacceptable. They may be considered as furnishing directions to others, where to look for some of the most interesting objects; and may afford to future travellers a small portion of the information which my guide, Dr. Shuter, so liberally communicated to me. That gentleman having long resided in the island, had repeatedly traversed it, and was thereby able to point out to me some of the circumstances which were most worthy of examination, particularly the nature of the various strata that are exposed to view in the deep and abrupt valleys which intersect the island in all directions. These valleys are no Jess picturesque to the eye of the coinmon traveller than they are deserving of the attention of the geologist. They are in general narrow and deep, the summits of the hills that form their boundaries are broken into peaks rugged and bare, while their sides are covered with the cedar and other trees peculiar to southern latitudes, and with a profuse variety of shrubs and plants, among which the erica arborea is the most beautiful, and in the greatest quantity.

The island of Madeira (though I believe it never has been surveyed) is said to be about 50 miles in length, and in its broadest part about 20 , but the average breadth does not exceed 15 miles.

It consists of a succession of lofty hills rising rapidly from the sea, particularly on the eastern and northern extremities. The summits of many of these ranges present the appearance of what has been called a table land; yet occasionally the forms are conical, and surmounted by a peak, which in some instances I found to be of columnar basalt. Deep ravines or valleys descend from the hills or serras ta the sea, and in the hollow of most of them flows a small river, which in general is rapid and shallow. The soil of the island is clay on the surface, and large masses of it as hard as brick are found underneath. Though there are not at present any existing volcanoes in the island, yet the remains of two craters are to be seen, one on the eastern, the

- From Transactions of the Geological Society, vol. i.

other 
other on the western side, the largest being about a Portuguese league, or four English miles, in circumference. Every thing around wears marks of having suffered the action of fire; yet I was unable to discoven any deposit of sulphur, and was told that none had hitherto been found in the island.

The varieties of strata, which I shall term generally lava, are not numerous. I myself saw but four, and I was informed there were no more to be met with. Three of them were invariably alternating in the same order. The first or lowest lava is of a compact species, containing few, if any, extraneous substances, is of a blue colour, and of a remarkably fine grain. Upon that, the second, which is a red earthy friable lava, rests; sometimes separated by beds of clay mixed with pumice, and layers of black ash and pumice. This red lava contains minute pieces of olivine; sometimes it assumes a prismatic form, and in one place was of a moderate degree of hardness : the principal springs of water in the island issue from this stratum. On the top is the third, a grayish lava, generally compact, thongh at times near the surface very cellular, and containing much olivine. This lava takes principally the prismatic form of basalt. I have seen it in the most perfect prisms from 30 to 40 feet or more in height, the surface being covered with scoria, ash, and pumice. These masses of lava contain more or less of what I consider to be olivine, occasionally carbonate of lime and zeolite, which last assumes either $\mathbf{a}$ crystallized or globular form, or is diffused in a thin coating between the difierent layers.

The fourth species of lava is of a coarse grain, is used for the making of walls, and the commonest and poorest houses are built of it, the blue and gray lavas being used for the copings, \&c. It works easier than the two other kinds above mentioned, is more friable and soft, and its colour is a mixture of brown and red. I observed it in a stratum by itself, and it did not seem to have any connexion with the other three kinds.

These are the principal stratified lavas that the island affords; but in the beds of the rivers, particularly in that which flows in the valley of the Corral, several varieties occur in isolated masses, containing olivine and zeolite in greater or less quantity, and exhibiting detached portions of strata, similar to those that are found in the Fossa Grande on the side of Vesuvius.

In the deep and singular valley called the Corral, which I had an opportunity of examining for several miles, the red and gray lava alternated five or six fimes. The tops of some 
of its barrier hills are formed of columnar basalt; here and there rising to a peak, or broken into what might be termed a crystallized ridge, or tapering to a point like the granite needles in the Mer de Glace. The columinar strata are found bere in all directions. They dip usually to the sea, but occasionally are dislocated in the most abrupt manner. Dykes of lava, rising perpendicularly to the horizon, intersect the strata at right angles. I saw one 200 or 300 feet in height, which cut through several of the alternations of the red and gray lava. This valley of the Corral well merits the most attentive examination; yet the journey there is one of some labour, and the walk down the river that flows in its bottom so difficult and toilsome, as almost to deter every one from the undertaking. We left the town of Funchal soon after day-break, and did not return till between eight and nine at night, having been, during the whole of that period, in a state of incessant exertion on horseback or on foot. The bed of the valley itself cannot be descended on mules or on horseback. The walk is eight or nine miles in length, and you are compelled to clamber over rocks, as there is not even a track, or wade in the bed of the river, which is rapid, and full of large and pointed stones. Some of the highest hills of the island border on this valley. Several of them rise from the bed of the river in a perpendicular height of 1000 or 1500 feet, judging only by the eye, and are what the French term taillé à pic. Others are broken into a succession of steep descents, and are covered with forests of wood and a profusion of plants. Down many there fall small cataracts of water, and some are hollowed into deep recesses, whence isșue from the lava numerous little streams that contribute to swell the principal river in the valley.

As you arrive on the brink of the Corral, after a ride of about ten miles from Funchal, you find yourself suddenly on the edge of a precipice, near to which a sort of traversing stair-case is cut, with a track winding to the bottom. On the right is a wall of lava nearly perpendicular from 400 to 500 feet in depth, composed of the two species of the red and gray, alternating five or six times, and assuming in its dislocation the form of a bow, both the lavas following in 2 regular bend the shape of the curve.

On the left of the stairs by which you are to descend, innumerable small columns of the gray lava project from the side: they dip N.W. and their form in general is quadrangular; but 1 found several of them in prisms of three, five, and six sides. They are remarkably small, and as 
they lie in this bed appear almost all to break off from each other at five or six inches in length, and I never found them exceed this size. They seem to form a dyke that cuts through the horizontal beds of lava.

At the edge of the descent there is a projection or range of basaltic columns, rising like a wall, tapering to the top, and separating into large quadrangular prisms. We found no black ashes in the valley of the Corral, though towards the bottom there are considerable strata of pumice, great masses of scoria, and cellular lava, and lava in a state of semi-vitrification; the whole presenting evident marks of an eruption, anterior to that which had formed these various strata of lava, which are visible from the summit of the hill to the bed of the river.

The dip of the strata is in general towards the sea. Basaltic columns shoot from the side of the ordinary strata, which are intersected by various dykes; and one of these in particular swept across both sides of the valley. There are here also rocks of about 100 feet in height, composed of a species of breccia. We examined one near the church, at the extremity of the winding stair-case, forming the descent into the valley, which was composed of large and small pieces of lava, some of them of many yards in length and depth, the angles being rounded, and the whole agglutinated together by a hard black earthy substance, that resisted all the force we could use to break off a piece of it. 'There are other rocks where the red lava forms the base, and these are soft.

On our road from Funchal to the Corral we saw a stratum of large nolules or balls of lava, composed of concentric layers similar to the coat of an onion, and lyiag one above another; the stratum exposed was 30 or 40 feet in depth, and appeared to go dowis to the bottom of the hill.

We also examined the coast to the westward of the town of Funchal. From the beach before the town to lllboo Castle, and beyond it to the land called the Punta de la Cruz, the general character of the coast is as follows: The red stone is the apparent base upon which rests a bed of gray prismatic lava, the stratum being sometimes from 40 to 100 feet in depth. At times this gray lava rests upon a deep bed of ashes and puwice, agglutinated together like the peperino and puzzolano in the vicinity of Naples. The scoria at the surface is remarkably thick, and all the upper parts of the lava appear to be cellular. The general dip of the lava on the coast near Funchal is to the morth, but near the 
fort of Illhoo it forms with a mass of pumice that is inter. sected with slight veins of carbonate of lime and zeolite, a rapid angle or curve of declination to the east. To the westward of the fort, the lava is not found for a little distance, and there is nothing but deep beds of pumice and the agglutinated mass above mentioned. These beds of pumice are of various thickness, the deepest appearing to be about four feet, and alternating with that stratum which I have called peperino. In different cavities of the pumice bed, there are large deposits of black ashes. Towards the extremity of the strata the red stone appears on the surface in a more solid state, and lies in prismatic masses, the prism being small, and not exceeding a few inches in diameter. Their substance is brittle, and crumbles with ease. This stratum of red lava is of a short continuance. Passing a small brook, it dips rapidly to the westward, and in its place the gray lava is found in a confused though sometimes prismatic form, and rises from the beach, while the red lava still runs along the surface to the height of near 100 feet, the top being covered with a thick scoria.

There is also in the vicinity of Funchal, to the eastward of the town, a fall of water, which, independent of the romantic beauty of the situation, merits being visited on account of the exposure of the two strata of lava in their relative position. The hills are composed wholly of lava, sometimes of a confused, sometimes of a prismatic formation, the red and gray lavas being visible on both sides of the valley. Near the head of it, a short distance from the cascade, the red stratum is at the bottom, and about 60 feet higher it re-appears, and again, about 200 feet higher, alternating with the gray lava. The upper red lava dips rapidly to the south, and the strata are disposed in the following manner:

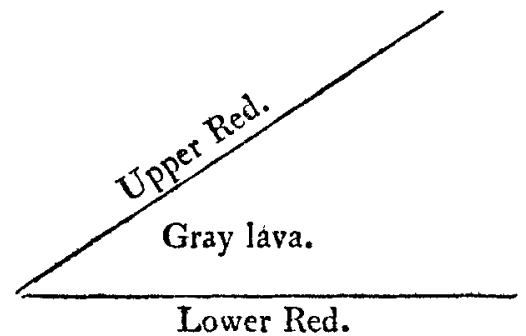

The rock, down which the cascade falls, is also intersect ed with a red stratum of about three feet wide, that traverses it, and dips to the westward, and is broken of by a broad 
On the Progress and present Stale of Vacciiation. 289

ilyke of gray lava. It appears about 30 feet higher, and dips again to the westward. The substance of the red rock in this place is hard, and it breaks into a columuar form, being by far the most compact of the red strata I met with in the island. I saw this red lava also in the island of Teneriffe, to the eastward of Santa Cruz, as well as in the neighbourhood of Orotava.

I have thus endeavoured to give you a slight sketch of that which appeared to me most deserving of attention in the island of Madeira. The short stay I was able to make there prevented a more accurate survey of the island; yet I saw enough to induce me to recommend a careful examination of the strata to those who may have more time than I had to spare, and more knowledge to estimate the value of that which was to be seen. 'To my mind, the most interesting genlogical facts are: 1 st, The intersection of the Java hy dykes at right angles with the strata. 2lly, The rapid dips the strata make, particularly the overlaying of that of the Brazen Head, to the eastward of Funchal, where the blue, gray, and red lavas are rolled up in one mass, and lie in a position as if they had all slipped together from an upper stratum. 3dly, The columnar form of the lava inself reposing on, and being covered by, beds of scorix, ashes, and pumice, which affords a strong arrument for the volcanic origin of the columns themselves : and thly, The veins of carbonate of lime and zeolite, which are not found here in solitary pieces as in the vicinity of $\mathbb{E}$ ina and Vesuvius, but are amid the lavas and in the strata of pumice and tufa, and are diffused on the lava itself, and uccasionaliy crystallized in its cavitics.

LIII. On the Progress and present State of the Praciice of Vaccination. By T. Bateman, M.D.

$\mathrm{T}$ me objects which the general adoption of vaccine innculation will accomplish for mankind, if tine and experience slatl confirm the promiscs of its benevolent discoverer, are so important, that every fricud of humanity must have followed with anxions hope the prorress of the practice, and rejoiced at the gencral result of the evidence in its favour. It is not cary, indecd, to calculate the sum of human misery that will cease to exist, when the prospect which vaccination holds out to us shall be realized. In its casual, or jatural occurence, as it is termed, the small-pox is not only Vol. 38. No. 16\%. Ot.1811. 